\title{
Does Dredging Of Floodplain Lakes Affects The Structure Of The Macrophytes And Epiphytic Fauna Inhabiting Stratiotes Aloides?
}

\author{
Martyna Bąkowska ${ }^{1,{ }^{*}}$, Krystian Obolewski ${ }^{1}$ and Ryszard Wiśniewski ${ }^{1}$ \\ ${ }^{1}$ Kazimierz Wielki University, Department of Hydrobiology, 85-064 Bydgoszcz, Poland
}

\begin{abstract}
Hydrotechnical activities on the Shupia river above the town of Stupsk (northern Poland) were performed against floods in the valley. The results based on the data on fauna and flora gathered before (in 2003, $T+0$ ) and after (in $T+2, T+6$ and $T+11$ ) the reclamation showed that the river canalization and oxbow lake dredging can significantly disturb the ecology of water bodies adjacent to the river. Observations of the oxbow lake (OLS5), showed the decrease in the number of macrophyte phytocenoses from 11 before the dredging to 6 very valuable Potametea phytocenoses, after wards. The development of common pleustonic phytocenoses of Lemnetea minoris and the massive development of green algae resulted from the bottom sediment removal. In the case of population, Stratiotes aloides was rebuilt after elimination during dredging already in $T+2$. Before hydrotechnical works, the oxbow lake was characterized by 12 invertebrate taxa inhabiting S.aloides, whereas only 9 were found first period after the dredging, 15 taxa in second period and 23 in a recent study. During both observation periods, dominated by Chironomidae larvae $(T+0)$, Trichoptera larvae $(T+2$ and $T+6)$ and again Chironomidae larvae $(T+11)$. The hydrotechnical activities significantly altered in the first period the structure of fauna and flora inhabiting the water body. Such radical interference in natural values of oxbow lakes is un-suitable for the preservation of ecosystems due to the significant decrease in their biodiversity. Achieved on a similar or higher level of macrophytes diversity and epiphytic invertebrates was noticeable ten years after the dredging of a water body.
\end{abstract}

\section{Introduction}

Oxbow lakes belong to those important aquatic ecosystems in floodplains which due to lentic character create suitable habitats for a significant number of macrophytes and invertebrates communities preferring stagnant water. Natural processes of succession in such water bodies lead to changes in the structure of fauna and flora. The intensive development of floodplain lakes can be restrained, to some extent, through reclamation activities, starting from the least invasive method as the oxbow lake re-connection with the river to the most radical method as the bottom sediment removal (dredging). The change of

* Corresponding author: bakowska@ukw.edu.pl 
environmental conditions as a result of dredging is substantial for the hydrobionts existence [1]. One of the symptoms of ecological decease of the ecosystem is the withdrawal of floating macrophytes including Stratiotes aloides L. (water soldier), a perfect natural substrate for epiphytic fauna in eutrophic and hyper-eutrophic water bodies [2-5].

Immersed or floating macrophytes play a particularly important role in intensively eutrophicated water body where anaerobic conditions at the bottom disable the existence of zoobenthos [6]. They become then "a second bottom" inhabited willingly by oxybionts $[7,8]$. Another important role of floating aquatic plants is delivery of food for aquatic fauna [9].

The paper is aimed at effects of oxbow lake dredging on fauna and flora inhabiting S.aloides as well as assessment of biological diversity of oxbow lakes under the influence of the reclamation works conducted in the river valley.

\section{Material and Methods}

The oxbow lake chosen for the research (called OLS5) is situated in the district of the

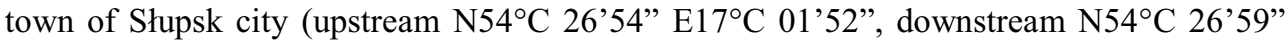
$\left.\mathrm{E} 17^{\circ} \mathrm{C} 01^{\prime} 57^{\prime \prime}\right)$. In 2003 , the object was dredged and deepened as an element of the complex restoration of flood-protection systems in the valley. As a result of dredging, the average depth of the water body increased from 1 to $2.5 \mathrm{~m}$, and the excavated material was placed along the banks of the floodplain lake. Similarly, to this water body, the other oxbow lakes along the river section were "re-freshed," as well.

Aquatic vegetation was studied twice, both before reclamation works in the period from April to July of $2003(T+0)$ and after wards in the same months in $2005(T+2), 2009(T+6)$ and $2014(T+11)$. Classification of the distinguished communities was con-ducted according to the commonly used methods [10]. Due to practical reasons, plant communities were distinguished with no syntaxonomical range. They are the base for the assessment of the dredging effects on the habitat conditions for hydrobionts.

Samples of floating S.aloides as well as epiphytic fauna inhabiting this species were collected in spring-summer periods 2003 and 2014. Each of eight samples collected from overgrown and then dredged oxbow lake consisted of $12-14$ representatives of S.aloides.

The samples were large enough to take off phytophilic fauna and the fauna from water solder. Calculations of the densities and biomass were done according to Obolewski et al. [8]. The Shannon index (H') was also determined to show effects of hydrotechnical activities on the diversity of the studied water body. The significant differences between structure of phytofauna amounts before and after the dredging were determined using twoway ANOVA tests at $p<0.05$.

\section{Results}

\subsection{Change in a vegetation cover}

The dredged oxbow lake was characterized by 11 plant communities in $T+0$ (Tab. 1) and represented by 3 classes: Lemnetea minoris, Potametea and Phragmitetea. The highest share among them had phytocenoses of Potametea R.Tx. et Prsg. The dominating community in the oxbow lake was Stratiotetum aloidis (Now. 1930) Miljan 1933. Characteristic species for that class was Stratiotes aloides and represented the highest share in the phytocenoses. It created a widespread compact cover, mainly at places of shallow and intensively insolated water. Besides the characteristic species, the society was abundant 
in the frog bit Hydrocharis morsus-rane, the greater duckweed Spirodela polyrhiza, the pond-weed Potamogeton natans and the canadian waterweed Elodea canadiensis. The other phytocenoses of Potametea class took relatively smaller areas and were represented by commonly exisitingexisting the broad leaf pondweed Potametum natantis Soo 1927, as well as valuable floristic societies of water lilies Nupharo-Nymphaeetum albae Tomasz. 1977 and the frog lily Hottonietum palustris R.Tx. 1937.

Table 1. List of systematic macrophytes communities in the floodplain lake before and after the hydrotechnical activities. (Explanation: + found occurrence, - no occurrence).

\begin{tabular}{|c|c|c|c|c|c|}
\hline & \multirow{3}{*}{ Syntaxon } & \multicolumn{4}{|c|}{ Dredged } \\
\hline & & \multirow{2}{*}{$\begin{array}{c}\text { Before } \\
T+0\end{array}$} & \multicolumn{3}{|c|}{ After } \\
\hline & & & $T+2$ & $T+6$ & $T+11$ \\
\hline & $\begin{array}{l}\text { Cl. Lemnetea minoris } \\
\text { O. Lemnetalia minoris } \\
\text { All. Lemnion gibbae }\end{array}$ & & & & \\
\hline 1 & $\begin{array}{l}\text { Spirodeletum polyrhizae } \\
\text { All. Riccio fluitantis-Lemnion trisulcae }\end{array}$ & + & ++ & ++ & + \\
\hline 2 & $\begin{array}{l}\text { Lemnetum trisulcae } \\
\text { Cl. Potametea } \\
\text { O. Potametalia } \\
\text { All. Potamion }\end{array}$ & + & ++ & ++ & ++ \\
\hline 3 & Ranunculetum circinati & + & - & - & - \\
\hline 4 & Como. Elodeetum canadensis & + & ++ & + & + \\
\hline 5 & $\begin{array}{l}\text { Comm. Ceratophyllum demersum } \\
\text { All. Nymphaeion }\end{array}$ & - & + & + & + \\
\hline & Hydrocharitetum morsus-ranae & + & - & $-/+$ & + \\
\hline 6 & Stratiotetum aloidis & ++ & $-/+$ & + & + \\
\hline 7 & Potametum natantis & + & - & - & $-/+$ \\
\hline 8 & $\begin{array}{l}\text { Nupharo-Nymphaeetum albae } \\
\text { All. Hottonion }\end{array}$ & + & - & + & + \\
\hline 9 & $\begin{array}{l}\text { Hottonietum palustris } \\
\text { Cl. Phragmitetea } \\
\text { O. Phragmitetalia } \\
\text { All. Phragmition }\end{array}$ & + & - & - & - \\
\hline 10 & Phragmitetum australis & + & - & + & + \\
\hline 11 & $\begin{array}{l}\text { Glycerietum maximae } \\
\text { Other communities }\end{array}$ & + & - & - & - \\
\hline & The communities of filamentous algae & - & ++ & $-/+$ & - \\
\hline
\end{tabular}

The presence of 2 societies and 2 plant communities as well as intensive development of chlorophytes (tab. 1) was stated after the dredging. The changes in light and thermal conditions caused the intensive development of pleustonic phytocenoses of Lemnetea minoris R. Tx. 1955. After the hydrotechnical activities, in the society of Spirodeletum polyrhizae dominated the lesser duckweed Lemna minor and the ivy leaf duckweed Lemna trisulca with sporadic share of the greater duckweed Spirodela polyrhiza. It shows a double-layer structure of vegetation with the bottom-rooted common hornwort Ceratophyllum demersum, that composed at many places its own phytocenoses, not noted before dredging.

As the consequence of dredging, 6 plant communities of Potametea and 2 of Phragmitetea classes disappeared. Phytocenoses with Stratiotetum aloidis were saved from the dredging only at blind side-canals. Probably, the dredging was too deep to maintain valuable macrophytes, including water lilies and the frog lily. The communities are particularly distinguishing due to esthetic values and the presence of endangered and 
protected species. Moreover, lakeside reeds of Phragmitetea R.Tx. et. Prsg. 1942 class were completely removed during the reclamation works.

\subsection{Change in the fauna colonizing Stratiotes aloides}

The highest density of invertebrates inhabiting S.aloides was stated in $T+0$, when in July it amounted to 102 ind. $\mathrm{kg}^{-1}$, and after dredging in July, $T+2$ (114 ind. $\left.\mathrm{kg}^{-1}\right)$. The maximal biomass was noted before dredging in May, when achieved $63.6 \mathrm{gWW} \mathrm{kg}^{-1}$ and, after hydrotechnical works in July $T+2$, reaching $\left(53.5 \mathrm{gWW} \mathrm{kg}^{-1}\right)$. Gastropoda and Chironomidae larvae determined the density and created groups of subdominants. However, only snails determined the biomass. During consecutive months, the share of snails in epiphytic fauna got lower as their amount decreased (Fig.1). Before dredging, the snails were represented by: Lymnaea stagnalis, Lymnaea tranculata, Lymnaea corvus, Acroloxus lacustris, Planorbarius corneus, Ancylus fluviatilis, Anisus leucostoma and Anisus vorliculus, whereas after the hydrotechnical works $(T+2)$ the following species disappeared, A. fluviatilis, A.leucostoma and A.vorliculus. In $T+6$ also appeared P. corneus, L. stagnalis, Bithynia tentaculata, Viviparus viviparous and in $T+11$ as well Lymnaea auricularia, Segmentina nitida and V.contectus.
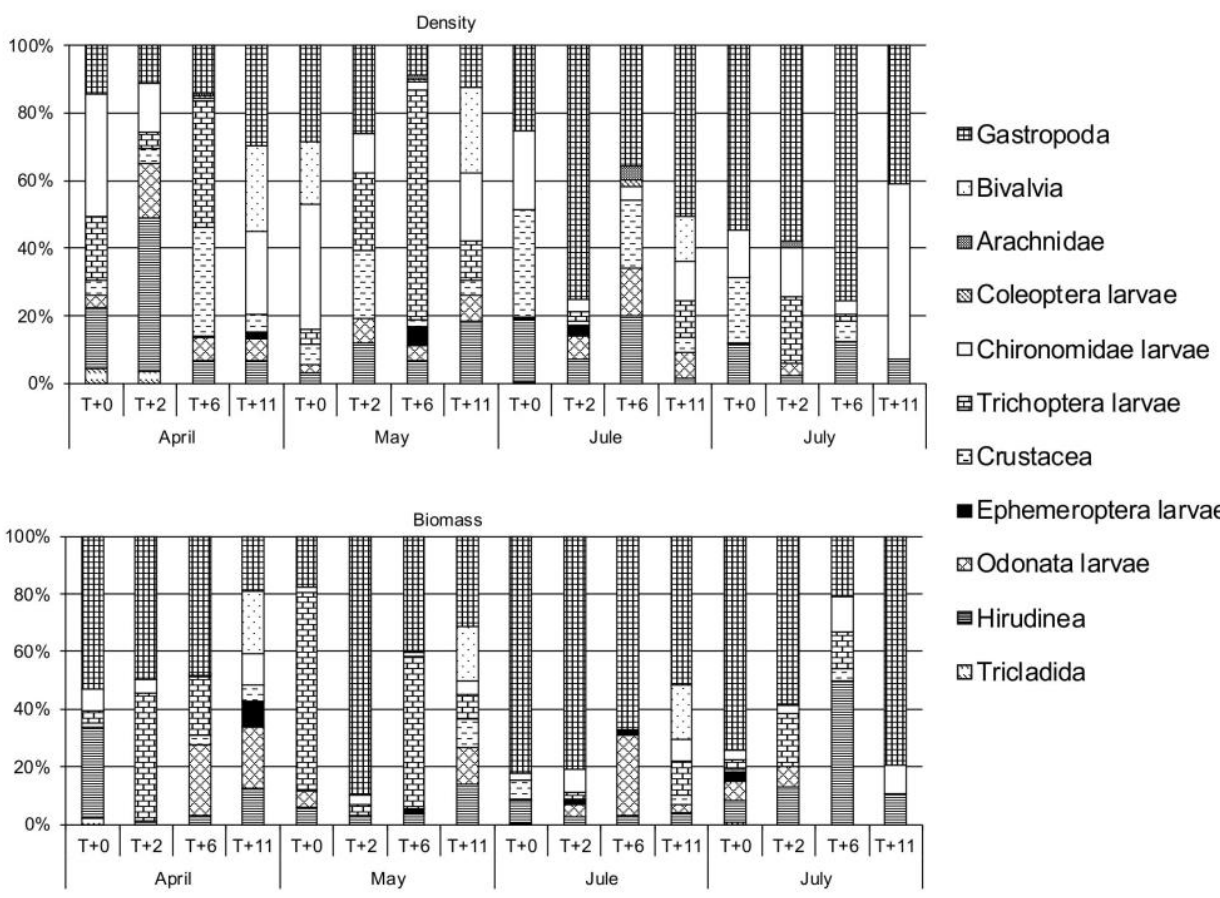

Ephemeroptera larvae

ఐOdonata larvae

EHirudinea

Tricladida

Fig. 1. The share of individual taxa of epiphytic fauna inhabiting Stratiotes aloides in the study floodplain lake $(T+0)$ before and $(T+2, T+6, T+11)$ after dredging.

In $T+0$, before the hydrotechnical works, the Hirudinea class was represented by Glossiphonia complanata L., Erpobdella sp., Helobdella stagnalis L. and Alboglossiphonia sp. The last species did not appeared after the reclamation. OLS5, when overgrown, created favourable conditions for the leech in April and the least convenient at the turn of April and May. After the dredging, the share of the leech in the epiphytic fauna was the lowest in June. The reclamation influenced the structure of leeches inhabiting $S$. aloides and caused 
the decrease in the leech density by 2 times and the decrease in its biomass by 3.5 times (Fig. 2).

Isopoda, represented by Asellus aquaticus, occurred only in the unchanged water body comprising both $13 \%$ of the total density (before $17 \%$, after $8 \%$ ) and the structure of epiphytic fauna. The dredging caused the complete withdrawal of A. aquaticus from $S$. aloides, particularly evident in $T+2$. The hydrotechnical works caused the decrease in the crustaceans density by 3 times and the decrease its biomass by 2 times.

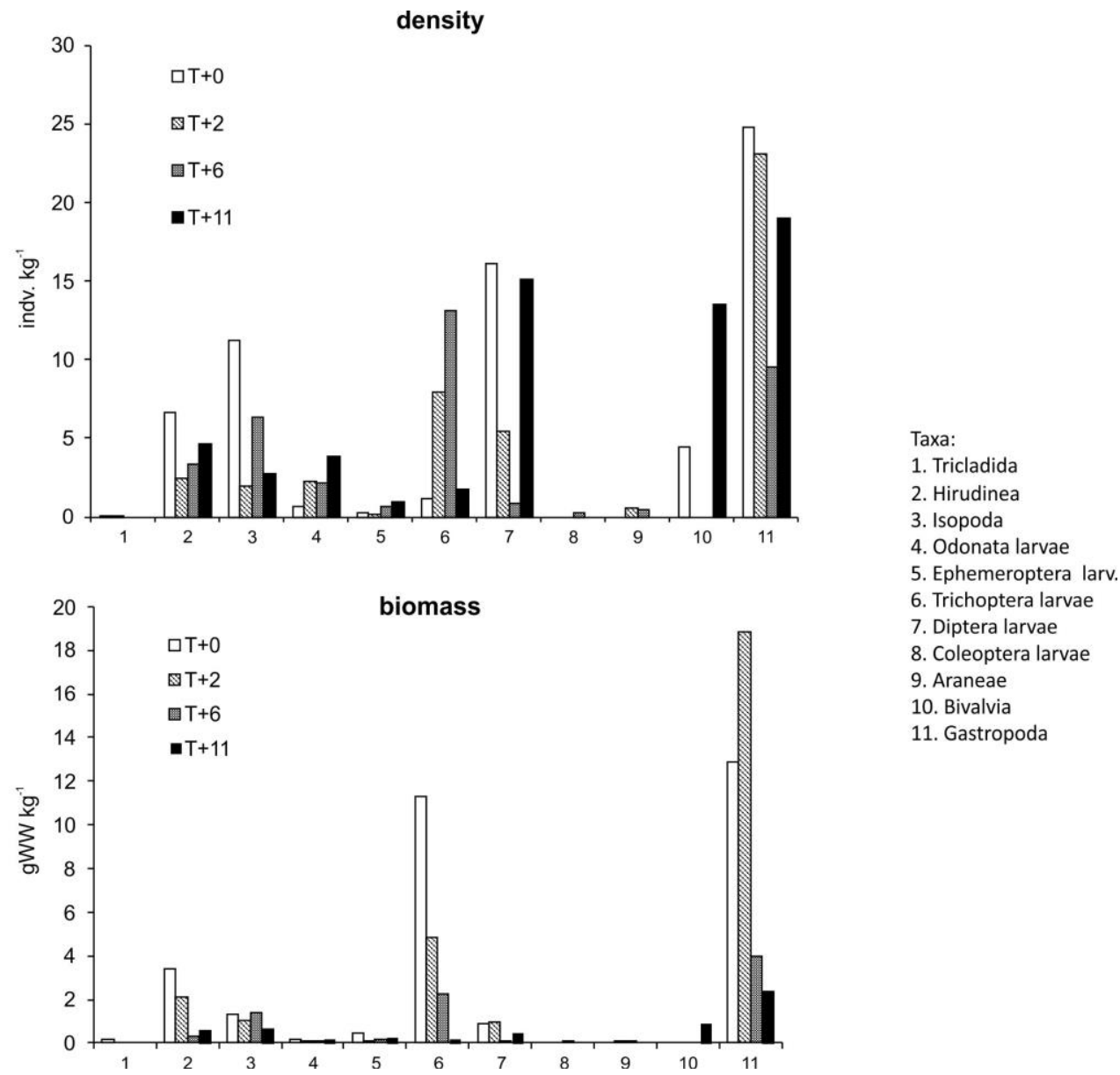

Fig.2. Changing the density and biomass of epiphytic fauna inhabiting S.aloides before $(T+0)$ and after $(T+2, T+6, T+11)$ dredging of floodplain lake.

The average share of dragonflies in the density and biomass of phytophilic fauna during both periods of observations was low (Fig.1). S.aloides, in the oxbow lake was permanently inhabited by dragonflies, which found the most convenient conditions for the development in April. Since that month, their share in epifauna systematically got lower, but increased in July. The density and biomass of dragonflies increased after the dredging (respectively 4 and 1.5 time, Fig.2). The reclamation of OLS5 seems to had negative influence on qualitive structure of Odonata represented by Ischnura sp., Lestes sp., Libellula sp. and Aeschna grandis.

Larvae of caddies-flies (Trichoptera) were developing the most intensively in May when they were an important element of fauna colonized S.aloides (Fig.1). Hydrotechnical works occurred not to threaten species of this order: after the dredging increased the density 
(6.5-times) and decreased biomass (6-times) of Trichoptera larvae (Fig. 2). The order represented Ecnomus tenellus, Limnephilus sp. and Lepidostoma sp. both before and after the oxbow lake dredging.

A significant element of epifauna existing outside and inside of S.aloides were representatives of Diptera larvae (Fig. 1). In April $T+0$ we found the highest biomass of these organisms, whereas in May their maximal abundance occurred. The share of Diptera larvae representatives decreased significantly after the dredging: more than 2.3 times in terms of abundance and almost 2 times in terms of biomass. In $T+11$ there was a reconstruction of Diptera abundance ( 15-16 indiv. $\left.\mathrm{kg}^{-1}\right)$, but at low biomass (Fig.2). The representatives of Diptera, dominated in inhabiting S.aloides in both periods of observations. It was mainly larvae of Bezzia sp., Eucricotopus sp., Psectocladius sp. and Chironomus sp.

In the collected samples from OLS5 we found also a representative of the Arachnids Argyroneta aquatic. The species were characterized by small biomass, taking only some per cent of total density and biomass of epifauna. The other systematic groups, including the ephemerid larvae (Caenis sp., Clëon sp., Leptophlebia sp.), Triclotida (Dendrocoelum lacteum), Coleoptera (Dytiscidae) and Bivalvia (Acroloxus lacustris, Sphaerium sp.), were sporadic on the biotic substrate. All of the taxa, excluding Triclotida, developed just after the biotic substrate was removed from the floodplain lake.

Radical interference in natural values of oxbow lakes is unsuitable for the preservation of ecosystems, due to the decrease diversity of fauna. The differences between number of taxa, densities and biomass of the fauna inhabiting the water body before and after the hydrotechnical works were not statistically significant in two-way ANOVA at $p<0.05$ (Table 2). But there were significant differences in diversity $(p=0.03)$ before and after the hydrotechnical works, and years of research. Comparison of the number of taxa and their density for the periods before and after dredging, vs. the years of study, showed statistically significant differences $(p<0.05)$. Despite visible differences in biomass of epiphytic fauna, they not shown to be statistically significant.

Table 2. Mean values ( \pm SE in parenthesis) of epiphytic macrofauna of floodplain lake during before dredging (BD) and after dredging (AD) time and results of two-way ANOVA tests evaluating the effects of time (BD vs. AD), year (Y), and time vs. Years.

\begin{tabular}{|c|c|c|c|c|c|}
\hline & \multirow{2}{*}{$\begin{array}{c}\text { Before } \\
\text { dredging } \\
\text { (BD) }\end{array}$} & \multirow{2}{*}{$\begin{array}{c}\text { After } \\
\text { dredging } \\
\text { (AD) }\end{array}$} & \multicolumn{2}{|c|}{ Source of variation $(F ; p)$} & \multirow[b]{2}{*}{$\begin{array}{c}\text { Time } \times Y \\
d f=17\end{array}$} \\
\hline & & & $\begin{array}{c}\text { Time } \\
(\mathrm{BD} \times \mathrm{AD}) \\
\mathrm{df}=1\end{array}$ & $\begin{array}{c}\text { Year }(Y) \\
\mathrm{df}=3\end{array}$ & \\
\hline No of taxa & 10 & 23 & $3.91 ; 0.06$ & $1.12 ; 0.38$ & $2.41 ; \mathbf{0 . 0 4}$ \\
\hline Diversity (nat ind ${ }^{-1}$ ) & $1.46 \pm 0.04$ & $1.38 \pm 0.12$ & $6.00 ; \mathbf{0 . 0 3}$ & $2.61 ; 0.04$ & $1.90 ; 0.09$ \\
\hline Total density (inds $\mathrm{m}^{-2}$ ) & $65.3 \pm 5.4$ & $47.3 \pm 8.1$ & $1.15 ; 0.29$ & $0.70 ; 0.56$ & $3.04 ; 0.01$ \\
\hline Total biomass $\left(\mathrm{gWW} \mathrm{m}^{-2}\right)$ & $30.67 \pm 4.85$ & $14.00 \pm 5.87$ & $1.46 ; 0.24$ & $0.92 ; 0.52$ & $0.93 ; 0.56$ \\
\hline
\end{tabular}

Bold values indicate significant differences

\section{Discussion}

Oxbow lakes in the Słupia river valley are overgrown by macrophytes preferring lentic and fertile water, surrounded by a zone of rushes. In deeper parts, immerse Potamion phytocenoses developed. They also play a pioneer role in the natural processes of getting shallow and overgrowing. During a further process, the phytocenoses are replaced by 
societies that belong to Nymphaeion, represented by the yellow water lily and the water lily Nupharo-Nymphaeetum albae, mainly. In OLS5, we noticed that the phytocenoses of Nupharo-N.albae were replaced by Stratiotetum aloidis. Before dredging, S.aloidis created a widespread and dense cover, mainly over shallow water, at easily heated, wind and wave protected places. Shortly after dredging water soldier gave way to, but rebuild the population after $T+6$ (Table 1).

Natural evolution of oxbow lakes is convenient for the development of the variety of fauna and flora species regardless of the stage of the floodplain lake overgrowing. The ecological role of macrophytes increases since they form not only a habitat for fauna but also their purifying role in the nutrient cycling in a lake [11]. Once, we noted that shorttime but drastic hydrotechnical activities easily disturbed this natural succession of a water body. Thus, extremely important to the ecosystem functioning is not to break this natural habitat. Achieved on a similar or higher level of diversity, density and biomass of epiphytic invertebrates was noticeable after ten years after the dredging of the water body.

An incrasing eutrophication and intensive biogeochemical processes occurring at the bot-tom of floodplain lakes causes the qualitative and quantitative loss in benthos species in such a water body $[11,12]$. Those unfavourable conditions make the macroinvertebrates species settle rushes and floating macrophytes [8, 13].

S.aloides, dominating among plants with floating leaves in OLS5, was inhabited by various taxa of aquatic fauna. Due to oxygen deficit in the bottom zone, the plant created the only alternative for the oxybionts existence [13-15]. Before dredging, S.aloides was inhabited by 8 - 10 taxa consisting of species characterized for macroivertebrates at amounts of 65.3 ind. $\mathrm{kg}^{-1}$ and biomass of $31 \mathrm{gWWkg}^{-1}$ of dry mass of the water soldier (tab. 2). As a result of dredging, bottom fauna species lost a significant substrate for the development, though the plant was replaced by green algae. As soon as bottom sediments were removed, oxygen conditions improved over the bottom. Hereafter, representatives of bottom fauna started settling their previous habitats [1]. Water soldier in the reclaimed OLS5 was inhabited by $15-23$ taxa, which initially $(T+2$ and $T+6)$ density decreased by 1.5-1.8 times, but the double increase in the biomass was limited by the Mollusca development.

The comparison of results on epifauna inhabiting S.aloides in different oxbow lakes showed that the most convenient conditions for the fauna settlement represent those water bodies with a permanent exchange of water from the rivers. It is confirmed by presenting the densities and Shannon diversity indices for other floodplain lakes [5, 16]. After dredging Shannon's index value decreased from $2.49(T+0)$ to $2.22(T+2)$ and then grew into value 2.60 in $T+6$ and 2.57 in $T+11$. All of the studied oxbow lakes are dominated by Gastropoda, intensively inhabiting S.aloides, except first period for an oxbow lake reconnected to the river called OLS5 (Trichoptera larvae) adjacent to the Stupia river. Malacofauna dominated in terms of biomass in each water body. Analysis of two-way ANOVA indicated no significant differences in epifauna densities and biomass in OLS5 before and after the dredging and only in case of diversity. Other comparisons showed no significant differences in means at $p<0.05$, even between dredged OLS5 and overgrown phase this oxbow lake. It indices that the hydraulic connectivity as a key factor influencing epifauna in-habiting S.aloides. The re-connection and permanent exchange of water between an oxbow lake and the river are safe and life-supporting also for many macrophyte phytocenoses. Any hydrotechnical activities within natural oxbow lakes should be preceded by a detailed analysis of biological and hydrological conditions in each water body to avoid losses of valuable elements of the ecosystems in river valleys. Changes in habitat quality affect biotic components of aquatic ecosystems $[8,17]$ and are reflected in the biodiversity of plant and animal assemblages $[18,19]$. 


\section{Conclusions}

1. River regulation, mainly dredging, conducted in the Słupia river valley destructively influenced macrophytes and the density of epifauna inhabiting aquatic plants, that caused the decrease in biological diversity of the oxbow lakes.

2. Due to phytocenotic and faunistic values, the use of naturally overgrowing oxbow lakes against flooding or retention purposes should be limited.

3. The hydrotechnical activities significantly altered in the first period $(T+2$ and $T+6)$ the structure of fauna and flora inhabiting the water bodies. Such radical interference in natural values of oxbow lakes is unsuitable for the preservation of ecosystems due to the significant decrease in their biodiversity. Achieved on a similar or higher level of diversity of epiphytic invertebrates was noticeable after ten years after the dredging of the water body.

4. Any hydrotechnical activities within natural oxbow lakes should be preceded by a detailed recognition of biological and hydrological conditions in each water body to avoid losses of valuable elements of the ecosystems.

\section{References}

1. K. Obolewski, Oceanol. Hydrobiol. St., 40(4), 52-63 (2011)

2. J. Kornatowski, Pol. Arch. Hydrobiol. 23, 365-376 (1976)

3. E.S. Brammer, Acta Univ. Ups. 540, 1-22 (1979)

4. J. Linhart, Acta Univ. Palacki. Olomuc., Fac. Rer. Nat., Biol. 37, 67-76 (1999)

5. K. Obolewski, K. Glińska-Lewczuk, N. Jarząb, P. Burandt, Sz. Kobus, R. Kujawa, T. Okruszko, M. Grabowska, S. Lew, A. Goździejewska, A. Skrzypczak, Pol. J. Environ. Stud., 23, 1679-1689 (2014)

6. S. Lalonde, J.A. Downing, Can. J. Fish. Aquat. Sci. 49, 992-1000 (1992)

7. L.W.G. Higler, Verh. Internat. Verein. Limnol. 19, 2773-2777 (1975)

8. K. Obolewski, A. Strzelczak, K. Glińska-Lewczuk, Ecol. Eng., 66, 72-81 (2014)

9. M. Tarkowska-Kukuryk, Pol. J. Ecol. 54, 441-451 (2006)

10. W. Matuszkiewicz, Guide to marking the plants assemblages of the Poland (PWN. Warszawa, 2001)

11. J. V. Ward, K. Tockner, D. B. Arscott, C. Claret, Freshwat. Biol. 47, 517-539 (2002)

12. K. Glińska-Lewczuk, A. Bieniek, P. Sowiński, K. Obolewski, P. Burandt, C.M. Timofte, J. Elem., 19, 361-376 (2014)

13. E. Suutari, J. Salmela, L. Paasivirta, M.J. Rantala, K. Tynkkynen, M. Luojumäki, J. Suhonen, J. Insect Conserv. 13, 413-419 (2009)

14. M. Strzałek, P. Koperski, Aquat. Bot. 90, 1-6 (2009)

15. M.J. Rantala, J. Ilmonen, J. Koskimäki, J. Suhonen, K. Tynkkynen, Aquat. Ecol. 38, 77-82 (2004)

16. K. Obolewski, K. Glińska-Lewczuk, Sz. Kobus, J. Elementol., 14, 119-135 (2009)

17. E. Wilk-Woźniak, S. Ligęza, E. Shubert, Clean - Soil, Air, Water 42, 421-427 (2014)

18. M.L. Pedersen, N. Friberg, J. Skriver, A. Baattrup-Pedersen, S.E. Larsen, Ecol. Eng. 30, 145-156 (2007)

19. L. Sartori, S. Canobbio, R. Cabrini, R. Fornaroli, V. Mezzanotte, J. Limnol. 74, 335-345 (2015) 